\title{
Effects of a manganese oxide-modified biochar composite on adsorption of arsenic in red soil
}

\author{
Zhihong Yu ${ }^{\mathrm{a}}$, Li Zhou ${ }^{\mathrm{a}}$, Yifan Huang ${ }^{\mathrm{a}}$, Zhengguo Song ${ }^{\mathrm{a} *}$, Weiwen Qiu \\ ${ }^{\mathrm{a}}$ Centre for Research in Ecotoxicology and Environmental Remediation, Agro-Environmental \\ Protection Institute, Tianjin 300191, China \\ ${ }^{\mathrm{b}}$ The New Zealand Institute for Plant and Food Research Limited, Private Bag 4704, Christchurch \\ 8140, New Zealand \\ Corresponding Author: Prof. Zhengguo Song \\ Tel./Fax. 0086-22-23616880 \\ Email: forestman1218@163.com
}

\begin{abstract}
The arsenic adsorption capacity of a manganese oxide-modified biochar composite (MBC), prepared by pyrolysis of a mixture of potassium permanganate and biochar, was investigated in red soil. Adsorption experiments using batch procedures were used to estimate the arsenic adsorption capacities of the absorbent materials. Adsorption and desorption isotherms, Fourier-transform infrared spectroscopy (FTIR), and X-ray photoelectron spectroscopy (XPS) were used to characterise the prepared adsorbent materials, and a plausible mechanism for arsenic removal by $\mathrm{MBC}$ was proposed. Arsenic in red soil-MBC mixtures exhibited lower mobility than that in soils amended with pristine biochar. The improved removal performance of soil-MBC mixtures was attributed to a lower $\mathrm{H} / \mathrm{C}$ ratio, higher $\mathrm{O} / \mathrm{C}$ ratio, higher surface hydrophilicity, and higher surface sorption capacity, even though the impregnation of manganese oxide decreased the specific surface area of the biochar. Arsenic retention increased as the biochar content increased, mainly owing to an increase in soil $\mathrm{pH}$. Several oxygenated functional groups, especially $\mathrm{O}-\mathrm{H}$, $\mathrm{C}=\mathrm{O}, \mathrm{Mn}-\mathrm{O}$, and $\mathrm{Si}-\mathrm{O}$, participated in the adsorption process, and manganese oxides played a significant role in the oxidation of arsenic. This study highlights the potential of MBC as an absorbent to immobilize arsenic for use in contaminated land remediation in the red soils region.
\end{abstract}

Keywords: Arsenic, adsorption, manganese oxide-modified biochar, red soil, oxidation

\section{Introduction}

Arsenic is a ubiquitous trace element that is potentially toxic to living organisms.

Arsenic originally derived from lithogenic sources occurs in surface soils, and can 
be mobilized through weathering reactions, biological activity, and geochemical reactions, which results in environmental implications. Anthropogenic activities, including uncontrolled industrial discharge from mining and metallurgical industries, combustion of fossil fuels, and the use of arsenic pesticides, herbicides, and crop desiccants, can create additional As contamination in soils, and surface and groundwater (Jiang and Singh, 1994; Mandal and Suzuki, 2002; Marin et al., 1993; Mohan and Pittman, 2007). Contaminated soils with arsenic levels over 1 $\mathrm{g} / \mathrm{kg}$ have been found in many countries around the world (Smith et al., 1998). The mobility, toxicity, and bioavailability of As in soil--water-plant systems depend on the species, and its sorption and desorption processes (Smedley and Kinniburgh, 2002; Violante and Pigna, 2002). The As(III) and As(V) oxidation states of As (arsenite and arsenate, respectively) are the primary forms of As in soils and aquifers (Ferguson and Gavis, 1972), and have different sorption behaviours (Arai et al., 2001; Goldberg and Johnston, 2001). Given this difference in behaviour, several methods have been commonly applied to remove As from contaminated soils or surface water, including precipitation, adsorption, membrane separation, ion exchange, and permeable reactive barriers. None of these methods are ideal, as each method has one or more disadvantages with a limited scope of application. For instance, some methods have proven too costly or are ineffective and require further remediation (Balasubramanian et al., 2009; Kumar et al., 2004; Leupin and Hug, 2005; Shih, 2005). Comparing all the advantages and disadvantages of the above-mentioned methods, adsorption processes are still considered highly efficient 
and low cost methods for removing As from soils or wastewater because of their cost-effectiveness, minimal by-product generation, and ease of operation (Bissen and Frimmel, 2003; Sullivan et al., 2010; Zhang et al., 2010). Many adsorbents have been developed for the removal of As, including activated carbon (Zhang et al., 2010), iron and iron compounds (Leupin and Hug, 2005; Simeonidis et al., 2011), manganese, zirconium (Luo et al., 2012), and biochars (Beesley et al., 2011; Kołodyńska et al., 2012; Song et al., 2014; Sun et al., 2014). Manganese-based materials are very effective for the removal and oxidation of arsenic (Lenoble et al., 2004). Because manganese oxides have positively charged mineral surfaces, they can increase the As(III) oxidation rate and allow increased adsorption of As(V) (Lafferty et al., 2010; Villalobos et al., 2014; Ying et al., 2012). Considering that $\mathrm{As}(\mathrm{V})$ is readily immobilised and has lower toxicity to humans than $\mathrm{As}(\mathrm{III})$, the oxidation of $\mathrm{As}(\mathrm{III})$ to $\mathrm{As}(\mathrm{V})$ in soils is an appropriate and practical process that has been recommended for remediation of As contamination.

Biochars (BC) produced by the high-temperature, low-oxygen pyrolysis of wood, rice husks, crop residues, and other agricultural wastes (Brewer and Brown, 2012; Glaser and Birk, 2012) can improve soil functions and reduce greenhouse gaseous emissions derived from organic materials. BC possesses a large surface area, and the negatively charged organic functional groups on the $\mathrm{BC}$ surface makes this a low-cost adsorption medium for retention of many heavy metals and control of contaminants in soils. Unlike cationic metals, As in the environment mainly exists in the form of oxyanions, which limits the As adsorption capacity of BC. Moreover, 
$\mathrm{BC}$ may raise the soil $\mathrm{pH}$, which could increase the mobility of As and cause plants to uptake As more readily (Joseph et al., 2010). Given these specific challenges when $\mathrm{BC}$ is utilised for reclamation of As, the impregnation of $\mathrm{BC}$ with Mn oxides to assist the immobilisation of As in soils can be a better option, as Mn oxides can limit As mobility via anion exchange in soils.

The red soils are major soils in southern China that have specific chemical, physical, and mineralogical characteristics. For the most part, these soils are highly weathered, acidic, poor in organic matter, and inherently infertile. They are highly susceptible to soil erosion, particularly on sloping land, and cannot sustain arable cropping systems without very careful management. In the past decades, large deposits of heavy metals in southern China have been mined to meet the demand of the nation's industrial development, causing enormous pollution challenges. The leakage or discharge of chemicals used for mining processes, such as As, can have adverse effects on the surrounding topsoil and aquifers, further increasing As bioavailability for plant uptake if protective measures are not taken. This can have a chronic toxic impact on the health of humans and animals if As-contaminated food and water are consumed.

The objectives of this work were to: (1) prepare and characterise a Mn oxide-modified biochar composite (MBC), (2) compare the As sorption capacity of $\mathrm{MBC}$ with that of pristine $\mathrm{BC}$, and (3) explore the possible mechanisms involved in the sorption of $\mathrm{As}(\mathrm{III})$ and $\mathrm{As}(\mathrm{V})$ by $\mathrm{MBC}$ in red soil. 


\section{Materials and methods}

\subsection{Materials}

All chemical reagents were purchased from the Guangfu Corporation (China). The red soil samples $(0-20 \mathrm{~cm})$ were collected from farmland in Yingtan county of Jiangxi province, China. The soil was mixed to obtain homogeneity using a nursery grade mixer and finally sieved through $0.75 \mathrm{~mm}$ nylon sieves for $\mathrm{pH}$ and CEC measurements or through $0.15 \mathrm{~mm}$ nylon sieves for organic matter content measurements. The $\mathrm{pH}$ of the red soil was 5.42 , the organic matter content was $14.90 \mathrm{~g} / \mathrm{kg}$, and the CEC was $5.90 \mathrm{cmol} / \mathrm{kg}$. Dried ground corn straw was used to prepare $\mathrm{BC}$.

\subsection{Sorbent preparation}

The synthesis of BC was described in a previous report (Kołodyńska et al., 2012). Briefly, untreated $\mathrm{BC}$ was produced from corn straw through slow pyrolysis at $600{ }^{\circ} \mathrm{C}$ for $2 \mathrm{~h}$ in a muffle furnace under a $\mathrm{N}_{2}$ atmosphere with a nitrogen flow rate of $300 \mathrm{~cm}^{3} / \mathrm{min}$. Untreated $\mathrm{BC}$ was included as an adsorbent for comparison. To prepare $\mathrm{MBC}, \mathrm{BC}(5 \mathrm{~g})$ was soaked in an aqueous $\mathrm{KMnO}_{4}$ solution $(0.079 \mathrm{~mol} / \mathrm{L}$, $40 \mathrm{~mL}$ ) for $24 \mathrm{~h}$ and then drained before pyrolysis at $600{ }^{\circ} \mathrm{C}$ for $0.5 \mathrm{~h}$ under a $\mathrm{N}_{2}$ atmosphere. The weight ratio of $\mathrm{BC}$ to $\mathrm{KMnO}_{4}$ was 10:1. The obtained samples were rinsed thoroughly, rewashed with deionized water to remove impurities, and dried at $80{ }^{\circ} \mathrm{C}$ in oven for $4 \mathrm{~h}$.

\subsection{Characterisation of $\mathrm{BC}$ and $\mathrm{MBC}$}

The carbon, hydrogen, and nitrogen contents of $\mathrm{BC}$ and $\mathrm{MBC}$ were determined by 
elemental analysis (Elementar Analysensysteme GmbH, Germany). The Mn content in $\mathrm{BC}$ and $\mathrm{MBC}$ was determined by atomic adsorption spectrometry (Zeenit 700), and the $\mathrm{pH}$ was measured using an electronic $\mathrm{pH}$ meter. The ash content of $\mathrm{BC}$ and MBC was defined as the mass remaining after pyrolysis at $750{ }^{\circ} \mathrm{C}$ in an open crucible until a constant weight was obtained. The volatile matter was defined as the weight loss after pyrolysis of $\mathrm{BC}$ or $\mathrm{MBC}$ at $950{ }^{\circ} \mathrm{C}$ for $7 \mathrm{~min}$ in a covered crucible (Uchimiya et al., 2011). The specific surface areas of BC and MBC were defined as the nitrogen adsorption, which was measured using a gas sorption analyser (Quantachrome, USA). X-ray photoelectron spectroscopy (XPS) measurements were conducted for the red soil and red soil amended with BC or MBC to examine adsorbed As (PHI 5000 Versa Probe, Physical Electronics, Inc.). 2.4. Adsorption and desorption isotherms Adsorption experiments were conducted by batch procedures to estimate the As(III) adsorption capacities of the absorbents. The experiments were conducted in $40 \mathrm{~mL}$ brown glass bottles, using $2.0 \mathrm{~g}$ red soil and $20 \mathrm{~mL}$ aqueous As(III) solution $(0,10$, $20,30,40$, and $50 \mathrm{mg} / \mathrm{L})$ at an ionic strength of $0.01 \mathrm{M}\left(\mathrm{NaNO}_{3}\right)$. The initial $\mathrm{pH}$ was adjusted to 7 with either $0.01 \mathrm{M} \mathrm{HCl}$ or $0.01 \mathrm{M} \mathrm{NaOH}$. $\mathrm{BC}$ or $\mathrm{MBC}(0,0.5 \%$, $1 \%, 2 \%$, and $4 \%$ of the soil weight) was added to the red soil. The reaction mixtures were agitated at $190 \pm 5 \mathrm{rpm}$ and $25{ }^{\circ} \mathrm{C}$ for $18 \mathrm{~h}$. Then, the supernatants were passed through filter paper (Whatman No. 42) and the filtrates were analysed for $\mathrm{As}(\mathrm{III})$ and $\mathrm{As}(\mathrm{V})$. All experiments were performed in triplicate. The treatments were: the red soil (S), red soil with BC (S-BC), and red soil with MBC (S-MBC). 
For the desorption experiments, $0.08 \mathrm{~g}$ of As-loaded adsorbents from the adsorption test was added to $40 \mathrm{~mL}$ of $0.05 \mathrm{~mol} / \mathrm{L} \mathrm{NaNO}_{3}$ solution after washing and drying. The vials were shaken at $150 \mathrm{rpm}$ for $48 \mathrm{~h}$ to reach an apparent equilibrium, and then the As(III) concentration in the solution was analysed.

\subsection{As analysis}

$\mathrm{As}(\mathrm{III})$ and $\mathrm{As}(\mathrm{V})$ were determined by hydride generation-atomic fluorescence spectroscopy (HG-AFS, AFS 9760, Beijing Haiguang Instrument Company, China) coupled with a hollow double-cathode lamp for As analysis. The detection limit for As was $0.05 \mathrm{ng} / \mathrm{mL}$. All samples were analysed within $24 \mathrm{~h}$. To assure accuracy, reliability, and reproducibility of the results, all tests were performed in triplicate. The average and variance in the arsenic concentrations are presented in the figures. A standard sample was run after every 10 samples. The recovery percentages were 90.5-109.5\%, and the relative standard deviations of the determination were less than $4.8 \%$.

\subsection{FTIR analysis}

The functional groups in $\mathrm{BC}$ and $\mathrm{MBC}$ were characterised using Fourier-transform infrared spectroscopy (FTIR) (Nexus 870, Nicolet, USA). A measured amount of $\mathrm{BC}$ or $\mathrm{MBC}$ was mixed with $\mathrm{KBr}(\mathrm{m} / \mathrm{m}=1: 200)$, ground into fine particles using a mortar and pestle, and compressed into a translucent sample disk by manual hydraulic pressure. Typically, thirty-two scans were collected.

\subsection{Statistical analysis}

All statistical analyses were conducted using SPSS 21.0 software (SPSS Inc., 
Chicago, IL). ANOVA was used to measure significant differences between treatments, with a $p$-value $<0.05$ indicating statistical significance.

\section{Results and discussion}

\subsection{Properties of BC and MBC}

Table 1 shows the elemental analysis and surface area analysis of BC and MBC.

The ash, volatile matter, and water contents, as well as the $\mathrm{pH}$, were not significantly different between BC and MBC ( $p>0.05)$. The Mn content in MBC was $7.41 \%$, whereas BC contained no Mn, suggesting successful Mn impregnation in MBC. The specific surface area dramatically decreased from 60.97 to $3.18 \mathrm{~m}^{2} / \mathrm{g}$ after impregnation, indicating that manganese oxide was successfully incorporated into the pores or clogged the pore openings on the $\mathrm{BC}$ surface in $\mathrm{MBC}$. The $\mathrm{O}$ content increased from $5.16 \%$ to $10.90 \%$ after impregnation, which may reflect an increased number of oxygen-containing functional groups in $\mathrm{MBC}$, indicating its potential for oxidation performance. Owing to the second pyrolysis step, the H/C ratio in MBC $(0.0045)$ was lower than that in $\mathrm{BC}(0.0205)$. Both values were lower than that reported (0.05) by Samsuri et al. (2013). BC with low H/C molar ratios has been shown to contain small amounts of organic residues from the original plant, such as cellulose, but have high carbonisation (Chun et al., 2004; Samsuri et al., 2013). The findings of our study indicate that the degree of carbonisation was higher in $\mathrm{MBC}$ than in $\mathrm{BC}$. The $\mathrm{O} / \mathrm{C}$ molar ratios for $\mathrm{BC}$ and $\mathrm{MBC}$ were 0.0605 and 0.1493 , respectively. This ratio is indicative of the content of polar groups content derived from carbohydrates and has been used as an indicator of surface 
hydrophilicity (Chun et al., 2004); thus, MBC is considered to have higher surface hydrophilicity than $\mathrm{BC}$. Hu et al (2015) also reported that the $\mathrm{O} / \mathrm{C}$ ratio is related to the oxygenated functional groups, which play a significant role in As sorption.

\subsection{Adsorption isotherms}

The Langmuir isotherm model (Equation (1)) was applied to describe the adsorption onto the treatments.

$$
q_{\mathrm{m}}=q_{\mathrm{e}} b C_{\mathrm{e}} /\left(1+b C_{\mathrm{e}}\right)
$$

Where $q_{\mathrm{m}}(\mathrm{mg} / \mathrm{g})$ is the maximum adsorption capacity, $b$ is the Langmuir adsorption constant $(\mathrm{L} / \mathrm{mg}), C_{\mathrm{e}}$ is the equilibrium concentration in the solution $(\mathrm{mg} / \mathrm{L})$, and $q_{\mathrm{e}}$ is the adsorption capacity at equilibrium (mg/g) (Xiong et al., 2010).

The Langmuir constants and correlation coefficients $\left(R^{2}\right)$ are shown in Table 2. The Langmuir equation assumes monolayer coverage of the sorbates over a homogenous sorbent surface and a finite number of identical absorption sites on the surface. The behaviour of As in the soil was closely associated with the amount of BC or MBC amended to the soil. Batch soil sorption experiments (Fig. 1) showed that very small amounts of As(III) were absorbed in red soil, whereas the S-BC and S-MBC samples showed better sorption ability. For all isotherms (Fig. 1), the adsorption of As increased with increasing equilibrium As concentration. The sorption process for all treatments can be well fitted by linear adsorption. The maximum adsorption capacities calculated using the Langmuir equation were 14.36 and $0.80 \mathrm{mg} / \mathrm{g}$ for $\mathrm{S}-\mathrm{MBC}$ and $\mathrm{S}-\mathrm{BC}$, respectively. The results indicated a high surface sorption capacity for arsenic on S-MBC. 
To better understand the differences in binding energy for As(III) between BC and MBC, desorption of $\mathrm{As}(\mathrm{III})$ was carried out in a $\mathrm{NaNO}_{3}$ solution. Fig. 2 clearly reveals that desorption of As(III) from all the samples declined dramatically on addition of MBC to the red soil. The maximum desorption rates of As(III) $(\%=$ desorbed amount of As(III)/corresponding adsorbed amount of As(III)) were calculated and followed the order of S (40\%) > S-BC (20.6\%) > S-MBC (7.9\%). Thus, the desorption data suggested that the addition of MBC could enhance adsorption of As(III) in red soil. It can be concluded that MBC has good potential to be used as an adsorbent for As(III) in red soil, as it is significantly more effective than pristine $\mathrm{BC}$ for $\mathrm{As}(\mathrm{III})$ adsorption.

\subsection{Effects of amount of $\mathrm{BC}$ and $\mathrm{MBC}$ on As adsorption}

The amount of $\mathrm{BC}$ amended to the red soil can influence the As removal efficiency. In this study, both $\mathrm{BC}$ and $\mathrm{MBC}$ improved the retention of As in the solid phase (Fig. 3). The results revealed that with increasing amounts of amended MBC, the adsorption of As in red soil significantly increased. However, the process was not the same in the presence of $\mathrm{BC}$. MBC adsorbed more As than $\mathrm{BC}$ at the same equilibrium concentration. By adding more MBC, greater adsorption capacity can be obtained in red soil. For instance, when the equilibrium concentration was 6 $\mathrm{mg} / \mathrm{L}$, the adsorption capacity was $0.5 \mathrm{~g} / \mathrm{kg}$ for $4 \% \mathrm{MBC}$, whereas it was only 0.25 , 0.30 , and $0.35 \mathrm{~g} / \mathrm{kg}$ for $0.5 \%, 1 \%$, and $2 \% \mathrm{MBC}$, respectively; however, the adsorption of As did not significantly change with the amount of $\mathrm{BC}$ amended to the soil. This result suggested that the enhanced adsorption capacity of As by red 
soil amended with MBC could be attributed to the greater degree of carbonisation, higher surface hydrophilicity, and increased number of oxygenated functional groups in MBC.

\subsection{Effect of $\mathrm{BC}$ and $\mathrm{MBC}$ on soil $\mathrm{pH}$}

Heavy metal removal is well known to have a considerable dependence on the $\mathrm{pH}$ of the soil. The $\mathrm{pH}$ of the soil was determined after the sorption experiments, and the results are presented in Fig. 4. The increases in soil $\mathrm{pH}$ were correlated with the amount of $\mathrm{BC}$ or $\mathrm{MBC}$ added. The $\mathrm{pH}$ increased by 1.4 units with $4 \% \mathrm{MBC}$ addition, whereas an increase of only 0.4 units was observed with addition of $4 \%$ BC. The $\mathrm{pH}$ of the soil increased from 5.42 to 6.35 and from 5.87 to 7.26 for additions of $\mathrm{BC}$ and $\mathrm{MBC}$ over the range of $0.5 \%$ to $4 \%$, respectively. We assume that the lower adsorption of As in the treatments with acidic $\mathrm{pH}$ was probably due to the presence of excess $\mathrm{H}^{+}$ions that compete with As for adsorption sites. With an increase in the soil $\mathrm{pH}$, the electrostatic repulsion between the positively charged As and $\mathrm{H}^{+}$ions is decreased, which may result in an increase in the removal of As in the MBC treatments. As such a $\mathrm{pH}$ increase can neutralise acid soil, $\mathrm{MBC}$ addition could also potentially prevent red soil acidification.

\subsection{FTIR analysis}

FTIR has been frequently used to analyse the surface functionalities in BC (Hassan et al., 2014). The FTIR spectra $\left(400-4000 \mathrm{~cm}^{-1}\right)$ of the soil amended with MBC before and after As adsorption are shown in Fig. 5. The bands around 3435, 2851, and $2929 \mathrm{~cm}^{-1}$ correspond to $\mathrm{O}-\mathrm{H}$ stretching vibrations and were characteristic of 
phenolic hydroxyl groups or adsorbed water (Huang et al., 2012; Luo et al., 2012). New peaks appeared after adsorption of arsenic at $2921 \mathrm{~cm}^{-1}$, which could be related to aliphatic $\mathrm{C}-\mathrm{H}$ vibrations, and at $1634 \mathrm{~cm}^{-1}$, which can be attributed to amide $\mathrm{C}=\mathrm{O}$ stretching, as observed mainly in proteins (Luo et al., 2012). It is noted that the band at approximately $1007 \mathrm{~cm}^{-1}$ in the spectra of the soils after adsorption was much stronger than that before adsorption; this band was attributed to the $\mathrm{Si}-\mathrm{O}$ stretching vibration. The peaks at 540 and $437.7 \mathrm{~cm}^{-1}$ could be related to the formation of Si-O-Mn bonds (Zhang et al., 2007); these bands were not observed in the treatment with $4 \% \mathrm{MBC}$ after As adsorption. This potentially could be explained by an interaction between $\mathrm{Mn}-\mathrm{O}$ and As. The FTIR analysis indicated the $\mathrm{Mn}$ in the MBC plays an important role in the adsorption process. In contrast, the FTIR spectra (Fig. 6) showed no significant differences between the treatments amended with different amounts of BC after As adsorption.

\subsection{XPS analysis}

Peaks in the XPS spectra in Fig. 7 are observed at electron binding energies of $532.31 \mathrm{eV}$ for $\mathrm{O} 1 s$, which represented $\mathrm{C}=\mathrm{O}$ or $\mathrm{O}-\mathrm{C}=\mathrm{O}$ bonds, and $\mathrm{Fe} 2 p_{3 / 2}$, indicating the presence of $\mathrm{Fe}(\mathrm{II})$ and $\mathrm{Fe}(\mathrm{III})$ in the oxide (Nesbitt et al., 1998). A peak at $643.34 \mathrm{eV}$ for $\mathrm{Mn} 2 p_{3 / 2}$ indicated the presence of $\mathrm{Mn}(\mathrm{II}), \mathrm{Mn}(\mathrm{III})$, and a small amount of Mn(IV) in the oxide, in either octahedral or tetrahedral holes, as the binding energies of $\mathrm{Mn}(\mathrm{IV}), \mathrm{Mn}(\mathrm{III})$, and $\mathrm{Mn}(\mathrm{II})$ species were very similar and the peak for $\mathrm{Mn}$ in low oxidation states was located on the low-energy side (Nesbitt et al., 1998). The spectra results shown in Fig. 8 show that some As was adsorbed 
on the surface of soil amended with MBC, whereas no As was observed on the soil surface amended by low amounts of $\mathrm{BC}$ and $\mathrm{MBC}$. Though the $\mathrm{O} 1 s$ quantity decreased, the adsorption capacity of the red soil amended with MBC was higher than that of other treatments, suggesting MBC plays an important role in the process of arsenic adsorption on the soil surface.

The XPS results showed that more As was absorbed into the soil amended with MBC compared with other treatments. From the XPS results (Fig. 7), a plausible mechanism for As(III) removal in the red soils amended with MBC could involve partial oxidation of As(III) to As(V) by Mn oxides and Fe-Mn oxides. Then, As(V) and As(III) are adsorbed on the surface via interactions with functional groups, diffuse into the interior, and finally, achieve equilibrium in the absorbent (Nesbitt et al., 1998; Ourvard et al., 2005).

\section{Conclusions}

$\mathrm{BC}$ and $\mathrm{MBC}$ were synthesised in the study to investigate their effects on adsorption of arsenic in red soil. The As adsorption data of $\mathrm{BC}$ and $\mathrm{MBC}$ were described well by Langmuir adsorption isotherms. The batch soil sorption experiments showed that S-MBC had a much greater sorption capacity for As(III) than the S-BC, although both enhanced the sorption of As(III) in red soil. The retention of As increased with the amount of added BC or MBC, mainly because of an increase in soil pH. FTIR and XPS analyses indicated that the adsorption of As occurred on the surface of the adsorbent, where $\mathrm{Mn}-\mathrm{O} / \mathrm{As}$ bonds, $\mathrm{Fe}-\mathrm{O} / \mathrm{As}$ bonds, and other oxygenated function groups were formed during the adsorption process 
on the red soil surface. The XPS results suggested that As(III) removal in the S-MBC was achieved through partial oxidation of As(III) to As(V) by Mn oxides and $\mathrm{Fe}-\mathrm{Mn}$ oxides. In summary, MBC plays an important role in the adsorption of As and has the potential to prevent red soil acidification and improve soil quality. As biochars are inexpensive, the manganese oxide-modified biochar developed in this study can be used as a promising remediation absorbent to mitigate the risks of As contamination in red soils.

\section{Acknowledgment}

The authors are grateful for financial support from the National Science Foundation of China (41273136).

\section{References}

Arai, Y., Elzinga, E.J., Sparks, D.L., 2001. X-ray absorption spectroscopic investigation of arsenite and arsenate adsorption at the aluminum oxide-water interface. J. Colloid Interface Sci. 235, 80-88.

Balasubramanian, N., Kojima, T., Basha, C.A., Srinivasakannan, C., 2009. Removal of arsenic from aqueous solution using electrocoagulation. J. Hazard. Mater. 167, 966-969.

Beesley, L., Moreno-Jiménez, E., Gomez-Eyles, J.L., Harris, E., Robinson, B., Sizmur, T., 2011. A review of biochars' potential role in the remediation, revegetation and restoration of contaminated soils. Environ. Pollut. 159, 3269-3282.

Bissen, M., Frimmel, F.H., 2003. Arsenic-a review. Part II: Oxidation of arsenic and its removal in water treatment. Acta Hydrochim. Hydrobiol. 31, 97-107.

Brewer, C.E., Brown, R.C., 2012. Biochar. Compr. Renewable Energy 5, 357-384.

Chun, Y., Sheng, G., Chiou, C.T., Xing, B., 2004. Compositions and sorptive properties of crop residue-derived chars. Environ. Sci. Technol. 38, 4649-4655.

Ferguson, J.F., Gavis, J., 1972. A review of the arsenic cycle in natural waters. Water Res. 6, 1259-1274.

Glaser, B., Birk, J.J., 2012. State of the scientific knowledge on properties and genesis of Anthropogenic Dark Earths in Central Amazonia (terra preta de Índio). Geochim. Cosmochim. Acta 82, 39-51.

Goldberg, S., Johnston, C.T., 2001. Mechanisms of arsenic adsorption on amorphous oxides evaluated using macroscopic measurements, vibrational spectroscopy, and surface complexation modeling. J. Colloid Interface Sci. 234, 204-216.

Hassan, A.F., Abdel-Mohsen, A.M., Fouda, M.M.G., 2014. Comparative study of calcium alginate, activated carbon, and their composite beads on methylene blue adsorption. 
Carbohydr. Polym. 102, 192-198.

Hu, X., Ding, Z., Zimmerman, A.R., Wang, S., Gao, B., 2015. Batch and column sorption of arsenic onto iron-impregnated biochar synthesized through hydrolysis. Water Res. 68, 206-216.

Huang, L., Kong, J., Wang, W., Zhang, C., Niu, S., Gao, B., 2012. Study on Fe(III) and Mn(II) modified activated carbons derived from Zizania latifolia to removal basic fuchsin. Desalination 286, 268-276.

Jiang, Q.Q., Singh, B.R., 1994. Effect of different forms and sources of arsenic on crop yield and arsenic concentration. Water, Air, Soil Pollut. 74, 321-343.

Joseph, S.D., Camps-Arbestain, M., Lin, Y., Munroe, P., Chia, C.H., Hook, J., van Zwieten, L., Kimber, S., Cowie, A., Singh, B.P., Lehmann, J., Foidl, N., Smernik, R.J., Amonette, J.E., 2010. An investigation into the reactions of biochar in soil. Soil Res. 48, 501-515.

Kołodyńska, D., Wnętrzak, R., Leahy, J.J., Hayes, M.H.B., Kwapiński, W., Hubicki, Z., 2012. Kinetic and adsorptive characterization of biochar in metal ions removal. Chem. Eng. J. 197, 295-305.

Kumar, P.R., Chaudhari, S., Khilar, K.C., Mahajan, S.P., 2004. Removal of arsenic from water by electrocoagulation. Chemosphere 55, 1245-1252.

Lafferty, B.J., Ginder-Vogel, M., Sparks, D.L., 2010. Arsenite oxidation by a poorly crystalline manganese-oxide 1. Stirred-flow experiments. Environ. Sci. Technol. 44, 8460-8466.

Lenoble, V., Laclautre, C., Serpaud, B., Deluchat, V., Bollinger, J.C., 2004. As(V) retention and As(III) simultaneous oxidation and removal on a $\mathrm{MnO}_{2}$-loaded polystyrene resin. Sci. Total Environ. 326, 197-207.

Leupin, O.X., Hug, S.J., 2005. Oxidation and removal of arsenic (III) from aerated groundwater by filtration through sand and zero-valent iron. Water Res. 39, 1729-1740.

Luo, X., Wang, C., Luo, S., Dong, R., Tu, X., Zeng, G., 2012. Adsorption of As (III) and As (V) from water using magnetite $\mathrm{Fe}_{3} \mathrm{O}_{4}$-reduced graphite oxide- $\mathrm{MnO}_{2}$ nanocomposites. Chem. Eng. J. 187, 45-52.

Mandal, B.K., Suzuki, K.T., 2002. Arsenic round the world: A review. Talanta 58, 201-235.

Marin, A.R., Pezeshki, S.R., Masschelen, P.H., Choi, H.S., 1993. Effect of dimethylarsenic acid (DMAA) on growth, tissue arsenic, and photosynthesis of rice plants. J. Plant Nutr. 16, 865-880.

Mohan, D., Pittman, C.U., Jr., 2007. Arsenic removal from water/wastewater using adsorbents-A critical review. J. Hazard. Mater. 142, 1-53.

Nesbitt, H.W., Canning, G.W., Bancroft, G.M., 1998. XPS study of reductive dissolution of $7 \AA$-birnessite by $\mathrm{H}_{3} \mathrm{AsO}_{3}$, with constraints on reaction mechanism. Geochim. Cosmochim. Acta 62, 2097-2110.

Ouvrard, S., de Donato, P., Simonnot, M.O., Begin, S., Ghanbaja, J., Alnot, M., Duval, Y.B., Lhote, F., Barres, O., Sardin, M., 2005. Natural manganese oxide: Combined analytical approach for solid characterization and arsenic retention. Geochim. Cosmochim. Acta 69, 2715-2724.

Samsuri, A.W., Sadegh-Zadeh, F., Seh-Bardan, B.J., 2013. Adsorption of As(III) and As(V) by Fe coated biochars and biochars produced from empty fruit bunch and rice husk. J. Environ. Chem. Eng. 1, 981-988.

Shih, M.C., 2005. An overview of arsenic removal by pressure-driven membrane processes. 
Desalination 172, 85-97.

Simeonidis, K., Gkinis, T., Tresintsi, S., Martinez-Boubeta, C., Vourlias, G., Tsiaoussis, I., Stavropoulos, G., Mitrakas, M., Angelakeris, M., 2011. Magnetic separation of hematite-coated $\mathrm{Fe}_{3} \mathrm{O}_{4}$ particles used as arsenic adsorbents. Chem. Eng. J. 168, 10081015.

Smedley, P.L., Kinniburgh, D.G., 2002. A review of the source, behaviour and distribution of arsenic in natural waters. Appl. Geochem. 17, 517-568.

Smith, E., Naidu, R., Alston, A.M., 1998. Arsenic in the soil environment: A review. Adv. Agron., 64, 149-195.

Song, Z., Lian, F., Yu, Z., Zhu, L., Xing, B., Qiu, W., 2014. Synthesis and characterization of a novel $\mathrm{MnO}_{\mathrm{x}}$-loaded biochar and its adsorption properties for $\mathrm{Cu}^{2+}$ in aqueous solution. Chem. Eng. J. 242, 36-42.

Sullivan, C., Tyrer, M., Cheeseman, C.R., Graham, N.J.D., 2010. Disposal of water treatment wastes containing arsenic-A review. Sci. Total Environ. 408, 1770-1778.

Sun, J., Lian, F., Liu, Z., Zhu, L., Song, Z., 2014. Biochars derived from various crop straws: Characterization and Cd(II) removal potential. Ecotoxicol. Environ. Saf. 106, 226-231.

Uchimiya, M., Wartelle, L.H., Klasson, K.T., Fortier, C.A., Lima, I.M., 2011. Influence of pyrolysis temperature on biochar property and function as a heavy metal sorbent in soil. J. Agric. Food Chem. 59, 2501-2510.

Villalobos, M., Escobar-Quiroz, I.N., Salazar-Camacho, C., 2014. The influence of particle size and structure on the sorption and oxidation behavior of birnessite: I. Adsorption of As(V) and oxidation of As(III). Geochim. Cosmochim. Acta 125, 564-581.

Violante, A., Pigna, M., 2002. Competitive sorption of arsenate and phosphate on different clay minerals and soils. Soil Sci. Soc. Am. J. 66, 1788-1796.

Xiong, L., Yang, Y., Mai, J., Sun, W., Zhang, C., Wei, D., Chen, Q., Ni, J., 2010. Adsorption behavior of methylene blue onto titanate nanotubes. Chem. Eng. J. 156, 313-320.

Ying, S.C., Kocar, B.D., Fendorf, S., 2012. Oxidation and competitive retention of arsenic between iron- and manganese oxides. Geochim. Cosmochim. Acta 96, 294-303.

Zhang, S., Qu, H., Liu, J., Liu, P., Li, T., 2007. Removal mechanism of As(III) by a novel Fe-Mn binary oxide adsorbent: Oxidation and sorption. Environ. Sci. Technol. 41, 4613-4619.

Zhang, S., Niu, H., Cai, Y., Zhao, X., Shi, Y., 2010. Arsenite and arsenate adsorption on coprecipitated bimetal oxide magnetic nanomaterials: $\mathrm{MnFe}_{2} \mathrm{O}_{4}$ and $\mathrm{CoFe}_{2} \mathrm{O}_{4}$. Chem. Eng. J. 158, 599-607. 


\section{Figure}

Fig.1.Arsenic adsorption isotherms

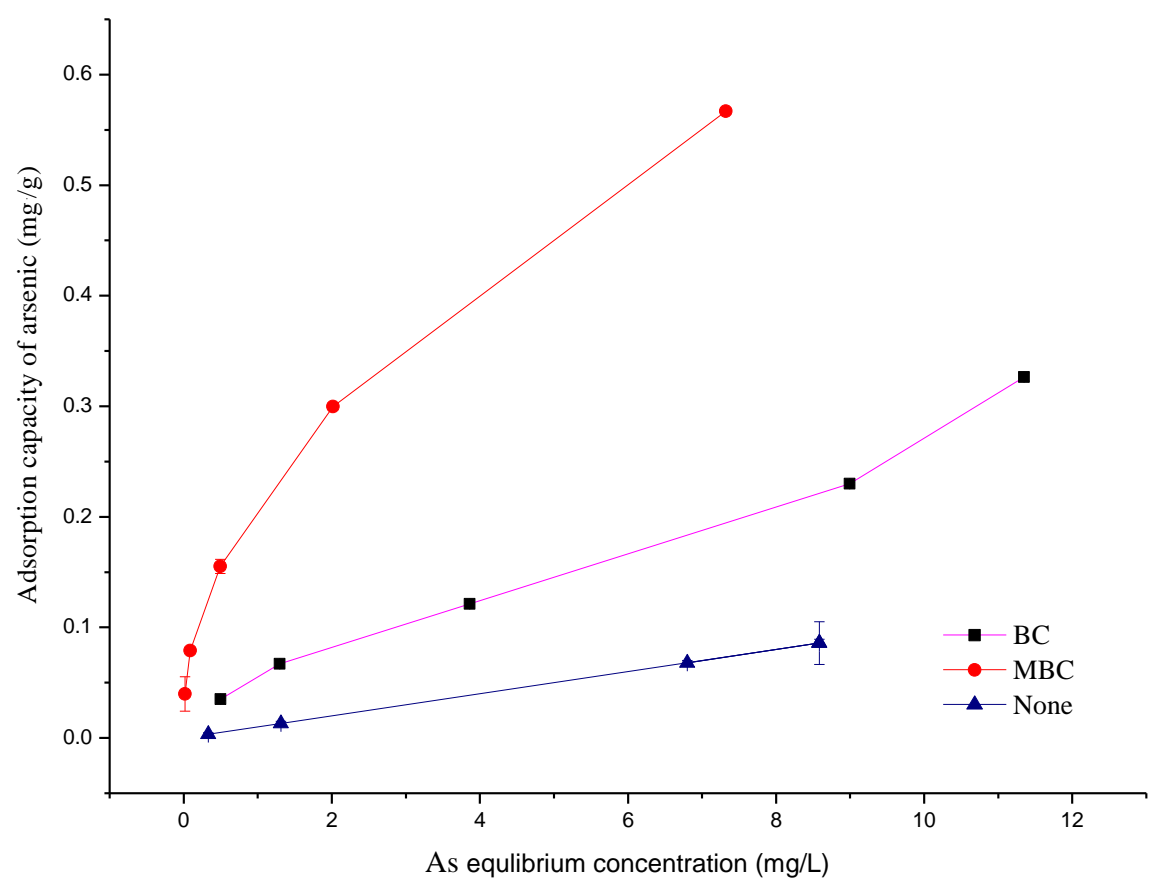


Fig.2. Arsenic desorption isotherms

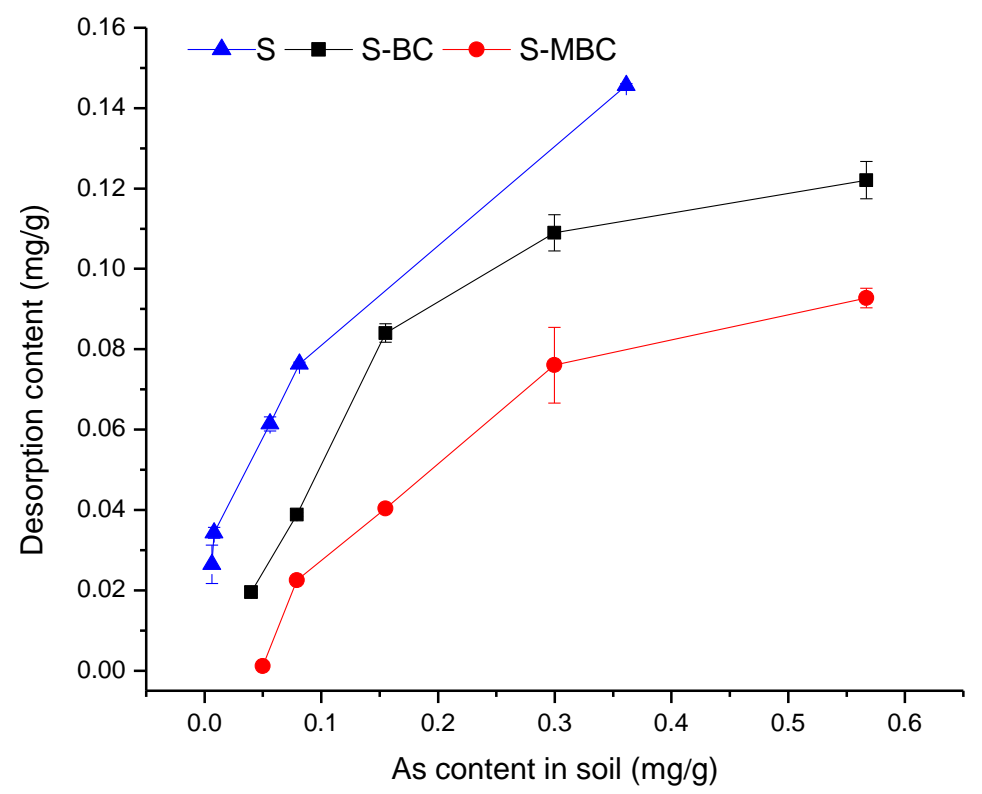


Fig.3. Influence of different additions of $\mathrm{MBC}(\mathrm{A})$ and $\mathrm{BC}(\mathrm{B})$ on the sorption of $\mathrm{As}$ in the red soil.

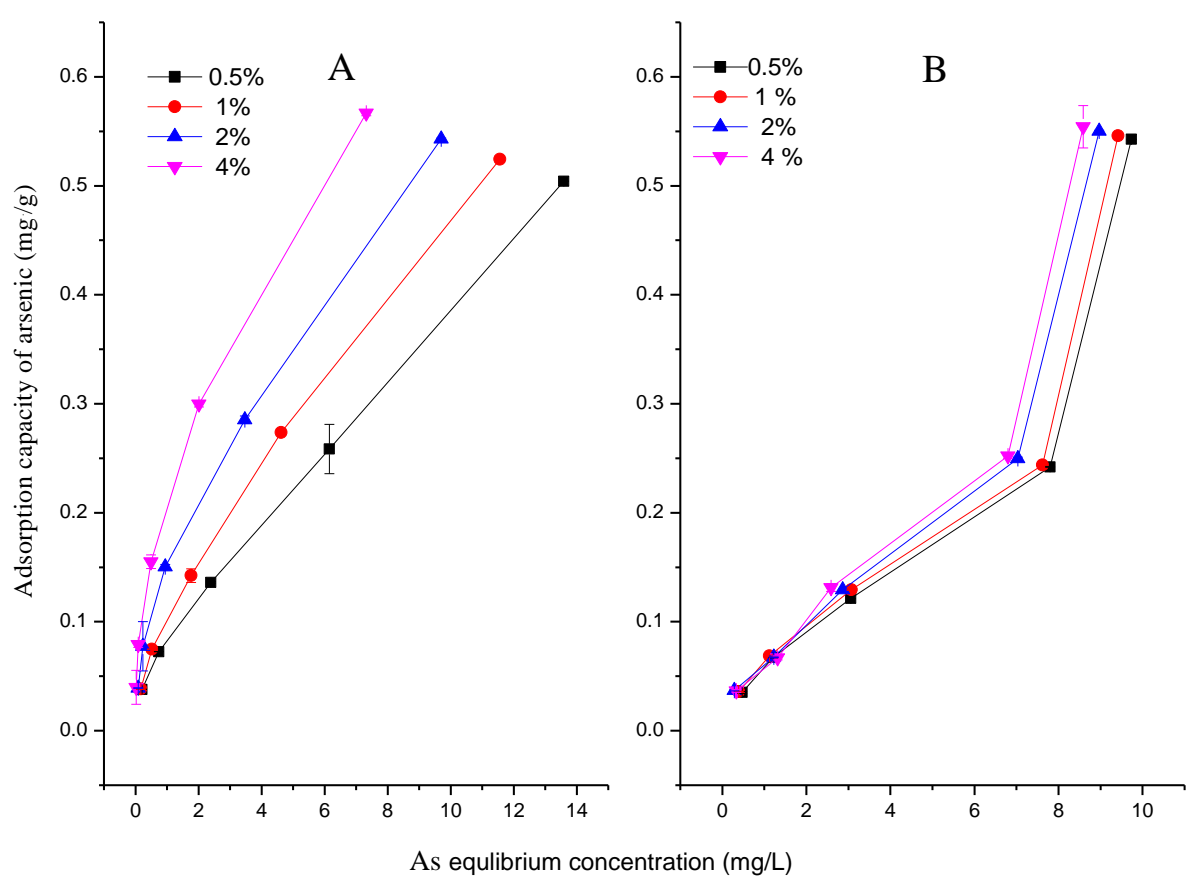


Fig.4. Soil $\mathrm{pH}$ after adding different rates of $\mathrm{BC}$ and $\mathrm{MBC}$

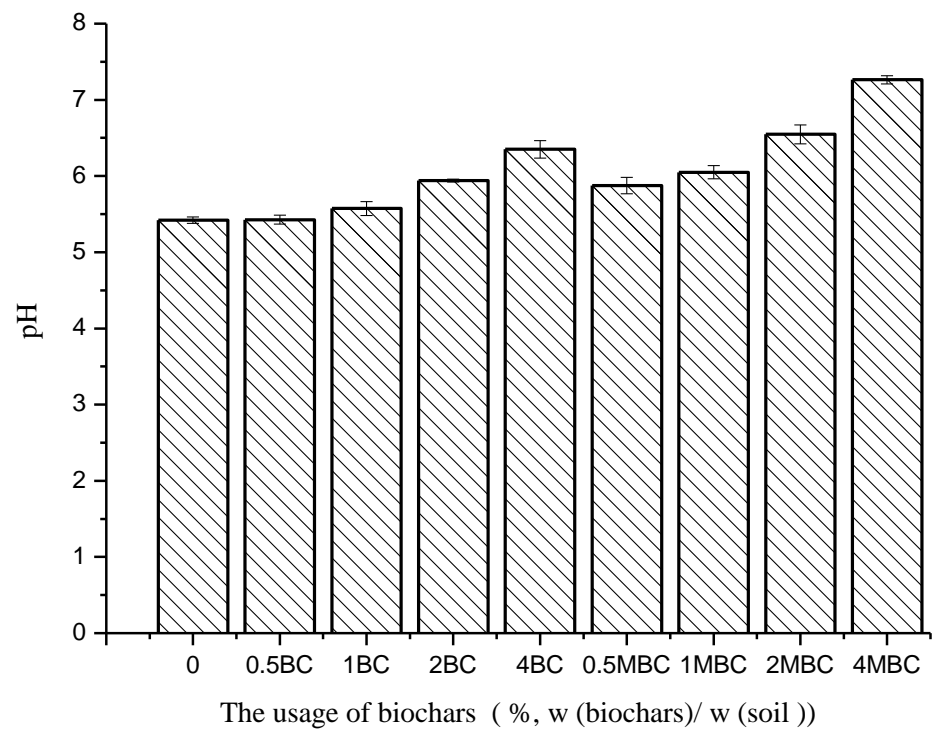


Fig.5. FTIR spectra of the red soil amended with various amount of MBC ( 0.01 , and $0.04 \mathrm{~g}$ per $\mathrm{g}$ soil) before and after adsorption of arsenic

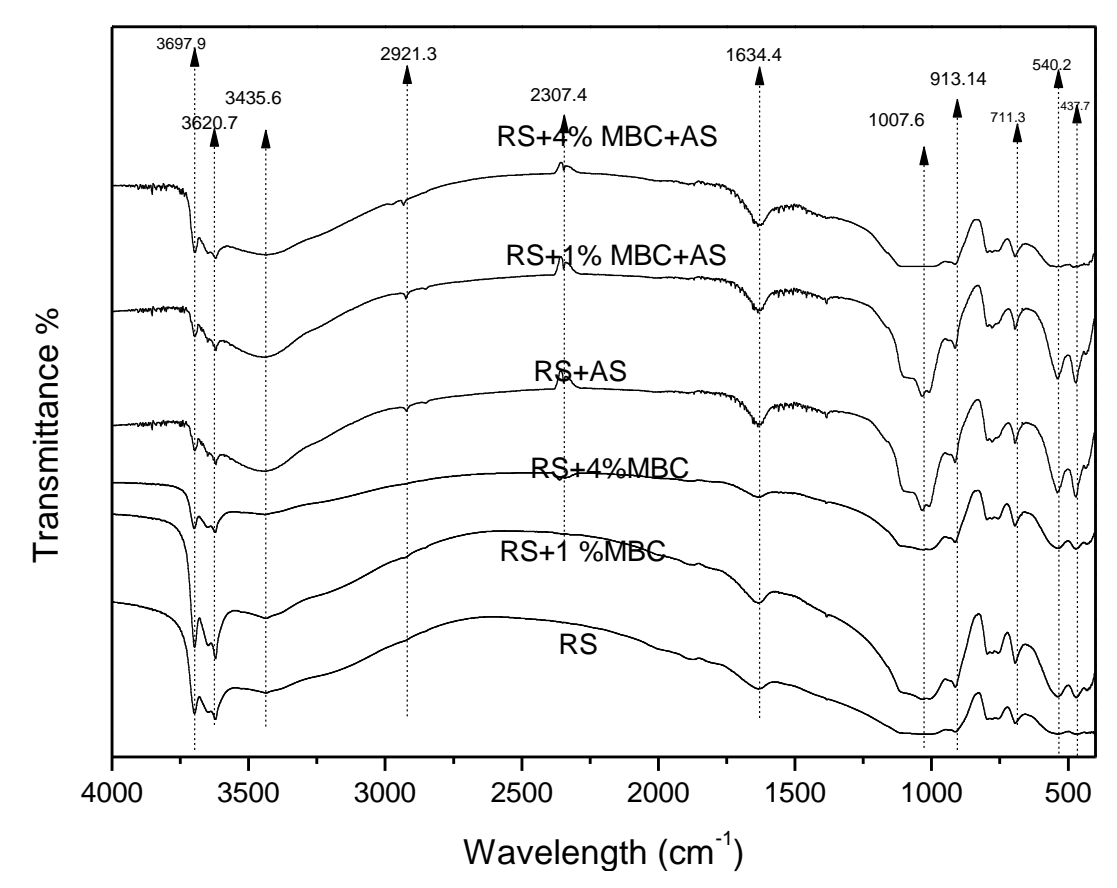


Fig.6. FTIR spectra of the red soil amended with various amount of biochars (BC and MBC) $(0.005,0.01,0.02$ and $0.04 \mathrm{~g}$ per $\mathrm{g}$ soil) after adsorption of arsenic

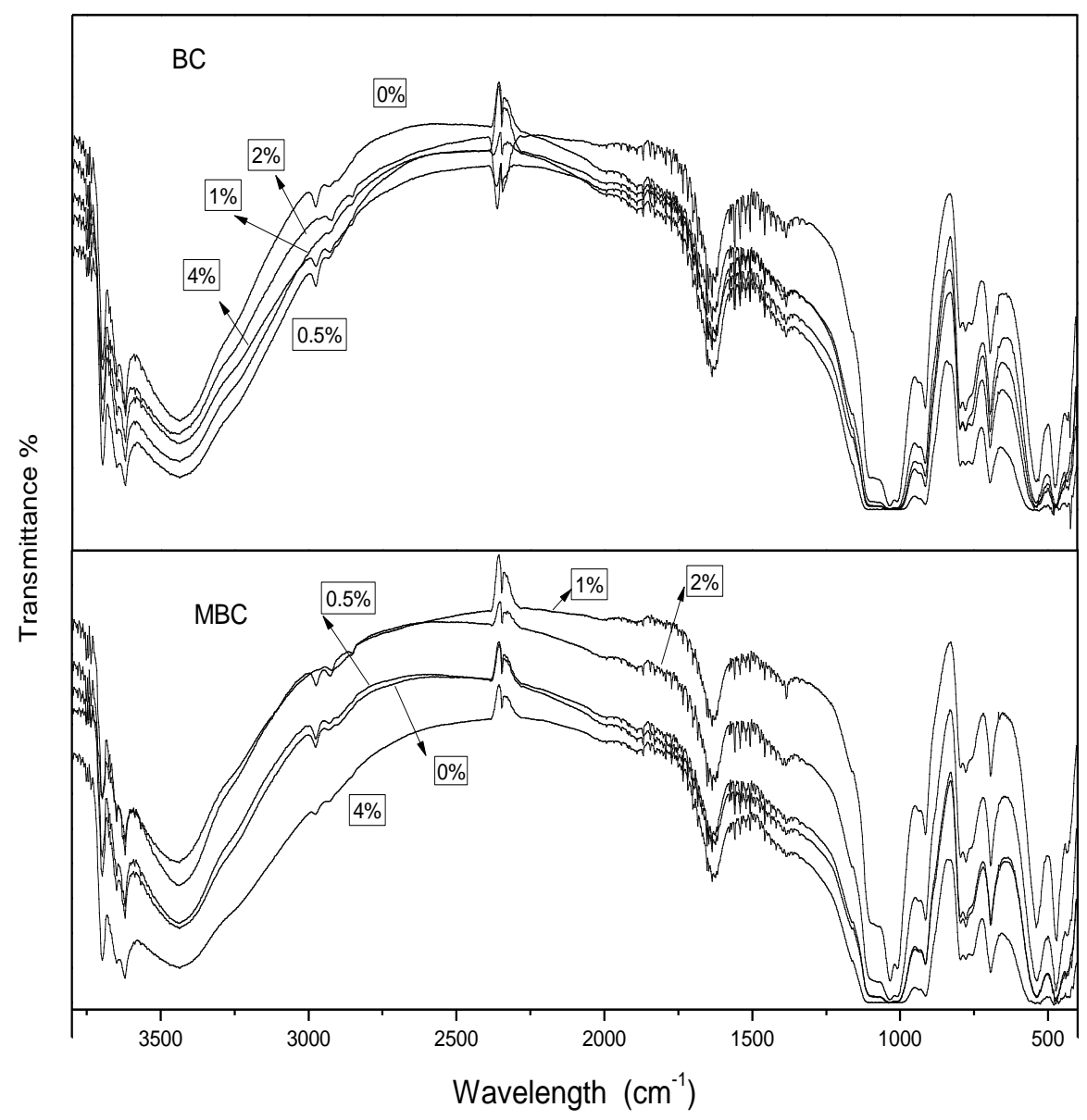


Fig.7. XPS spectrum of the red soil and mixture of soil with manganese oxides biochar adsorbed arsenic

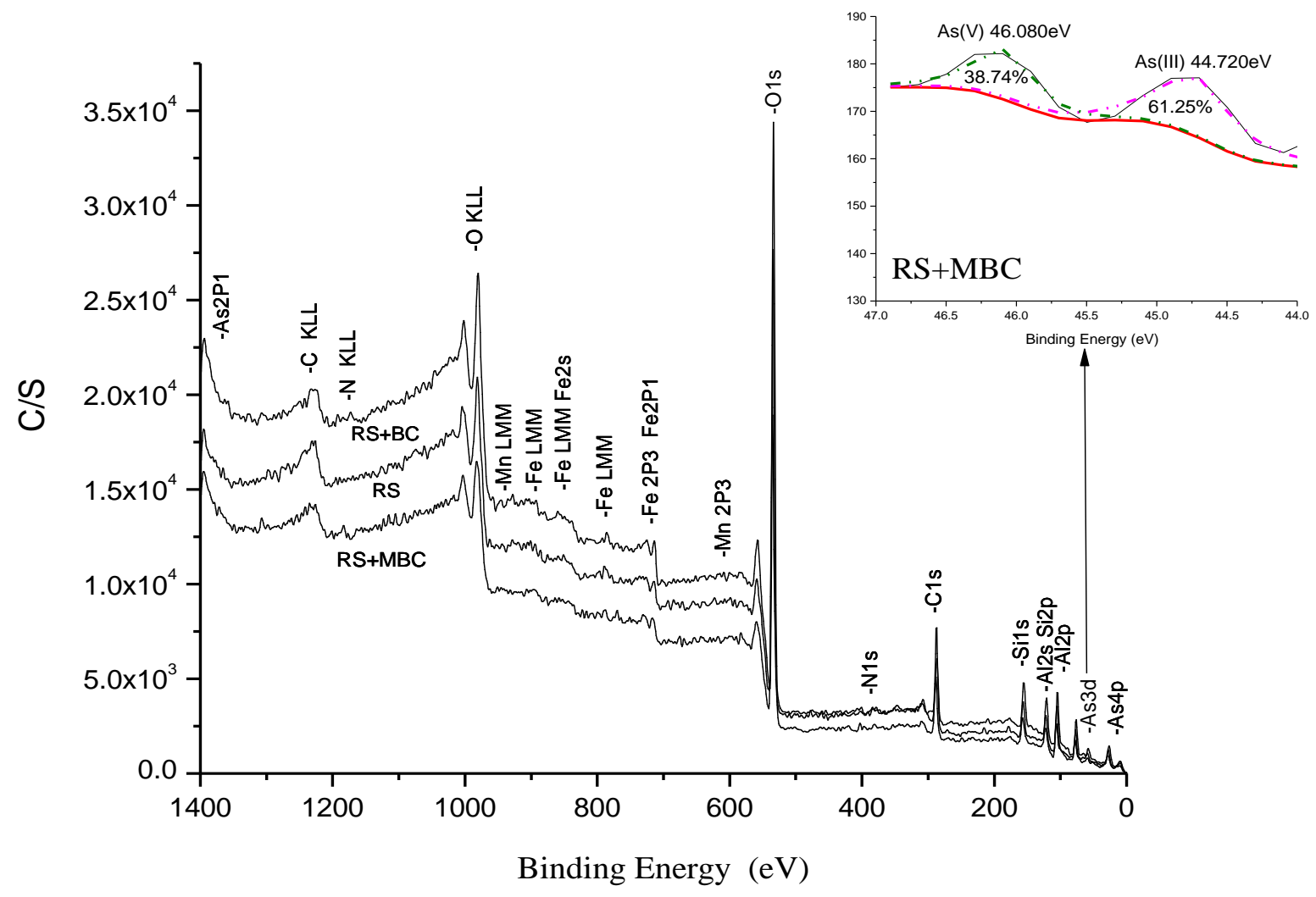


Fig.8. Mn and As atomic respective percent in XPS spectrum of the red soil and its various mixtures with biochar and modified biochar

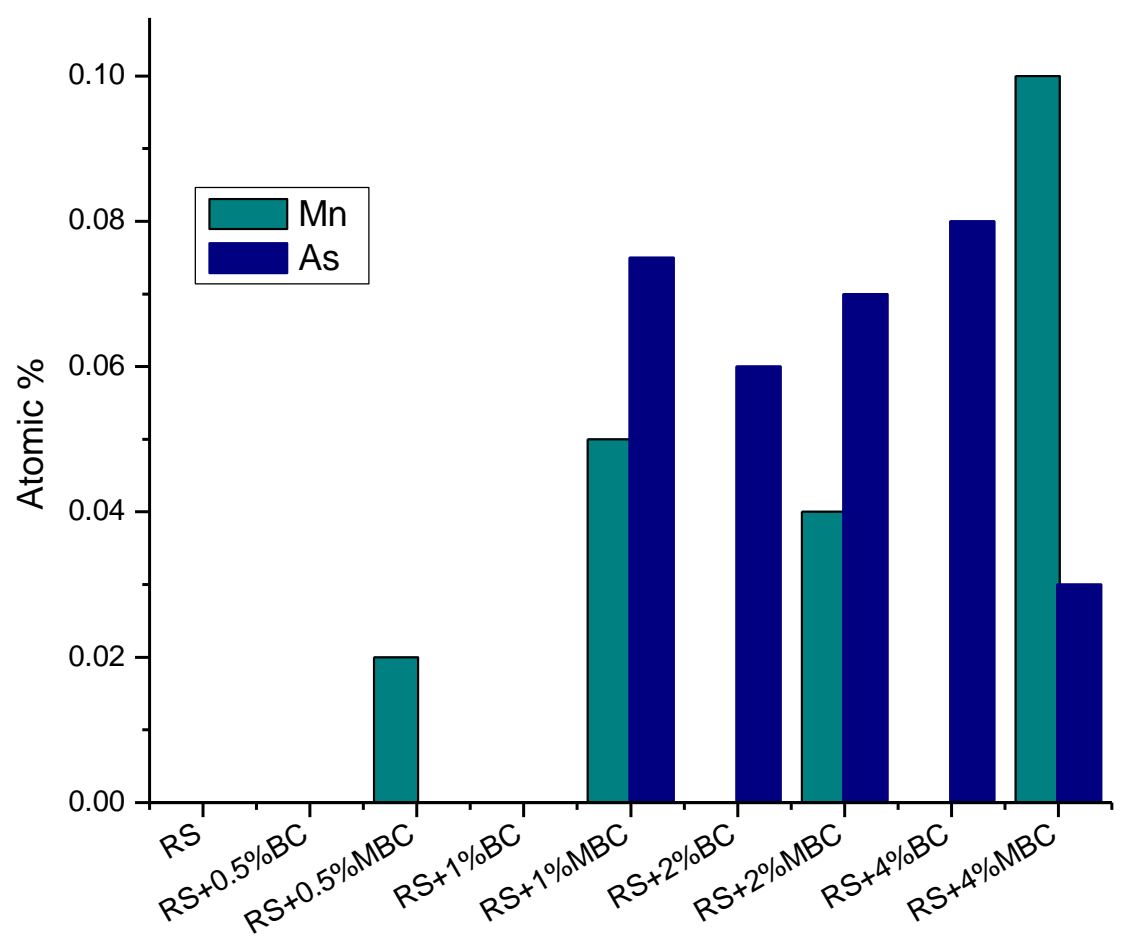

The usage of biochars ( \%, w (biochars)/ w (soil )) 


\section{Table}

Table 1 Physicochemical characteristics of biochar and manganese oxides-biochar composite

\begin{tabular}{|c|c|c|c|c|c|c|c|c|c|}
\hline \multirow{2}{*}{ Absorbent } & Ash & Volatile Matter & $\mathrm{Mn}$ & $\mathrm{N}$ & $\mathrm{C}$ & $\mathrm{O}$ & $\mathrm{H}$ & \multirow{2}{*}{$\mathrm{pH}$} & $\mathrm{S}_{\mathrm{BET}}$ \\
\hline & \multicolumn{7}{|c|}{$\%$} & & $\left(\mathrm{~m}^{2} / \mathrm{g}\right)$ \\
\hline $\mathrm{BC}$ & 10.17 & 9.32 & nd & 0.80 & 85.26 & 5.16 & 1.75 & 10.39 & 60.97 \\
\hline $\mathrm{MBC}$ & 12.60 & 9.76 & 7.41 & 0.72 & 73.00 & 10.90 & 0.33 & 10.75 & 3.18 \\
\hline
\end{tabular}

Note: $\mathrm{S}_{\mathrm{BET}}$ means specific surface area by BET analyzed.

Table 2 The constants and correlation coefficients $\left(R^{2}\right)$ of Langmuir model

\begin{tabular}{cccc}
\hline \multirow{2}{*}{ Treatments } & \multicolumn{3}{c}{ Langmuir } \\
\cline { 2 - 4 } & $q_{\mathrm{m}} /(\mathrm{mg} / \mathrm{g})$ & $\mathrm{b} /(\mathrm{L} / \mathrm{mg})$ & $\mathrm{R}^{2}$ \\
\hline $\mathrm{S}$ & 0.7785 & 0.0486 & 1 \\
$\mathrm{~S}-\mathrm{BC}$ & 0.8039 & 0.3206 & 0.9647 \\
$\mathrm{~S}-\mathrm{MBC}$ & 14.3618 & 0.0007 & 0.9640 \\
\hline
\end{tabular}

